\title{
Biogeochemical processes in a small California estuary. 1. Benthic fluxes and pore water constituents reflect high nutrient freshwater inputs
}

\author{
Jane M. Caffrey ${ }^{1, *}$, Neil Harrington ${ }^{2}$, Bess Ward ${ }^{3}$ \\ ${ }^{1}$ Center for Environmental Diagnostics and Bioremediation, University of West Florida, 11000 University Parkway, \\ Pensacola, Florida 32514-5751, USA \\ ${ }^{2}$ Department of Ocean Sciences, University of California Santa Cruz, 1156 High Street, Santa Cruz, California 95064, USA \\ ${ }^{3}$ Department of Geosciences, Guyot Hall, Princeton University, Princeton, 110 West College, Box 430, \\ New Jersey 08544, USA
}

\begin{abstract}
Elkhorn Slough, a small estuary in central California, receives nutrient inputs from agricultural and other non-point source runoff. To evaluate the effect of nutrient loading on ecosystem processes, rates of sediment oxygen consumption, benthic nutrient fluxes, pore water ammonium $\left(\mathrm{NH}_{4}{ }^{+}\right)$, dissolved inorganic phosphate (DIP) and sulfide $\left(\mathrm{S}^{2-}\right)$ concentrations were measured at 5 sites several times each year between 1998 and 1999. Two sites near the head of the slough receive direct runoff from agricultural fields, while the sites in the middle reaches and mouth receive direct runoff from grasslands and woodlands. Sites receiving agricultural runoff usually had high water column concentrations of dissolved inorganic nitrogen and chlorophyll a (50 $\mu \mathrm{M}$ and $30 \mu \mathrm{g} \mathrm{l}^{-1}$, respectively). High precipitation in the winter of 1998 caused low salinities in the slough at that time. In general, salinity and nutrient concentrations were inversely correlated. Sites receiving agricultural runoff had high pore water $\mathrm{NH}_{4}{ }^{+}$, DIP and dissolved $\mathrm{S}^{2-}$ concentrations, particularly in the summer. Oxygen penetration into sediments was the greatest at the sites adjacent to grasslands and woodlands, and least at the sites receiving high nutrient runoff. Sediment oxygen consumption was 4 times greater at sites near agricultural fields than the site near the mouth, while $\mathrm{NH}_{4}{ }^{+}$flux out of sediments was between 4 and 20 times greater at agricultural sites than at non-agricultural sites. This study suggests that high nutrient runoff has primarily a local rather than estuary-wide effect on sediment biogeochemical processes in Elkhorn Slough, perhaps due to longer water residence time at the head of the slough compared to the mouth.
\end{abstract}

KEY WORDS: Estuary · Eutrophication · Nutrients · Oxygen · Elkhorn Slough

\section{INTRODUCTION}

Nitrogen (N), phosphorus (P) and silica (Si) are essential elements controlling primary production in estuarine environments (Ryther \& Dunstan 1971, Howarth 1988, Conley \& Malone 1992). These cycles are interrelated by organic matter production and decomposition. In shallow estuarine environments, most

*E-mail: jcaffrey@bellsouth.net organic matter produced in the water column is decomposed and regenerated in sediments (Graf 1992, Kemp et al. 1992, Jørgensen 1996a). Within sediments, cycling of oxygen (O), carbon (C), N, P and sulfur (S) are intertwined as decomposition proceeds. Two electron acceptors that dominate organic $\mathrm{C}$ decomposition in sediments are $\mathrm{O}_{2}$ and $\mathrm{SO}_{4}{ }^{2-}$ (Mackin \& Swider 1989). At the sediment-water interface, $\mathrm{O}_{2}$ diffuses into sediments from the water column and aerobic processes such as aerobic respiration (estimated as sediment $\mathrm{O}_{2}$ consumption, SOC) dominate. Once $\mathrm{O}_{2}$ is 
depleted, other electron acceptors, $\mathrm{NO}_{3}^{-}, \mathrm{Mn}^{3+}, \mathrm{Fe}^{3+}$, $\mathrm{SO}_{4}{ }^{2-}$ and $\mathrm{CO}_{2}$, are used sequentially by heterotrophic bacteria. Decomposition by $\mathrm{SO}_{4}{ }^{2-}$ reducing bacteria produces $\mathrm{S}^{2-}$ and $\mathrm{NH}_{4}{ }^{+}$. $\mathrm{NH}_{4}{ }^{+}$produced in sediments can diffuse out into the overlying water or be oxidized to $\mathrm{NO}_{2}^{-}$and $\mathrm{NO}_{3}^{-}$by nitrifying bacteria, which are obligate aerobes. Any $\mathrm{NO}_{2}^{-}$or $\mathrm{NO}_{3}^{-}$present in sediments can also diffuse out, or be reduced back to $\mathrm{NH}_{4}{ }^{+}$ by dissimilatory $\mathrm{NO}_{3}{ }^{-}$reduction or reduced to $\mathrm{N}_{2}$ by the process of denitrification. Although $\mathrm{P}$ does not undergo oxidation-reduction reactions like $\mathrm{N}$, it binds to $\mathrm{FEOOH}$ under aerobic conditions. When $\mathrm{Fe}^{3+}$ is reduced, $\mathrm{P}$ becomes more available and its concentration increases in pore waters. In contrast to the other elements described, remineralization of $\mathrm{Si}$ is a chemical process, not mediated by bacteria or oxidationreduction reactions.

In addition to the availability of electron acceptors, rates of decomposition are dependent on the quantity and quality of organic matter in sediments. As organic matter production in the water column increases or as water depth decreases, decomposition in sediments increases (Kemp et al. 1992, Jørgensen 1996a). Decomposition rates are also dependent on the lability of organic matter, with refractory organic matter decomposing more slowly than labile organic matter (Westrich \& Berner 1984).

Eutrophication is an increasing problem within estuaries and the coastal zone because of increasing nutrient loads to these systems (Nixon 1995, Bricker et al. 1999, NRC 2000). Runoff from agricultural fields has long been recognized as a significant source of nutrients to many estuaries including Chesapeake Bay (Staver et al. 1996, Jordan et al. 1997), Neuse River (Paerl et al. 1995), North San Francisco Bay (Hager \&

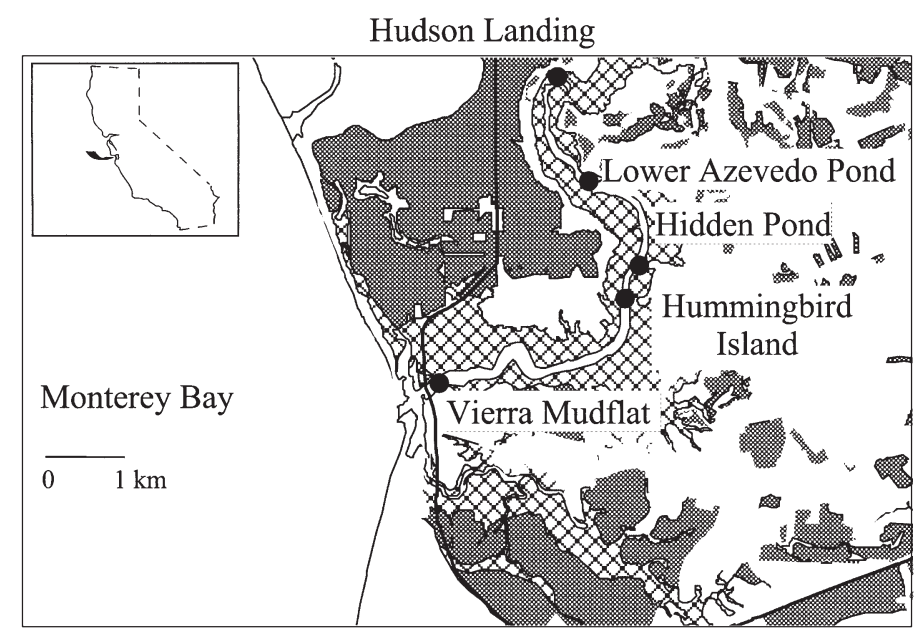

Fig. 1. Map of Elkhorn Slough, central California, showing station locations, marsh (crosshatch), and agricultural lands (stippled)
Schemel 1992), Roskilde Fjord (Kamp-Nielsen 1992), Scheldt estuary (Billen et al. 1985) and several Scottish estuaries (Balls 1994). The effect of agricultural runoff or any high nutrient runoff on estuaries can be modulated by the water residence time, stratification and other physical transport processes. Estuaries with low flushing rates may be more susceptible to eutrophication than well-flushed systems (NRC 2000, Cloern 2001). A possible mechanism is that as residence time increases, nitrogen export decreases (Nixon et al. 1996), leading to increased phytoplankton or macroalgal production which is then deposited to sediments. The effect of increased organic loading to sediments can be significant particularly as it affects the oxicanoxic interface and thus the balance between aerobic processes (e.g. SOC and nitrification) and anaerobic processes (e.g. sulfate reduction and denitrification) (Kemp et al. 1990, Caffrey et al. 1993, Jorgensen 1996a, Herbert 1999).

Interactions among nutrient loading, residence time and sediment/water fluxes were investigated in the present study in Elkhorn Slough, a small estuary, extending inland for $11.4 \mathrm{~km}$ from Monterey Bay in central California. The slough includes a variety of habitats that experience a range of freshwater/seawater exchanges and nutrient loading. Local environments in the slough, such as pocket marshes or tidal creeks, are important to wildlife and human usage of the site, and the characteristics of the main stem of the estuary are probably not representative of the great spatial and temporal variability experienced by other slough habitats. The slough is shallow (2.5 m water depth), with intertidal mudflats and pickleweed marsh Salicornia virginica bordering the main channel and tidal creeks. Extensive mats of macroalgae are found on the intertidal mudflats, while eelgrass Zostera marina colonizes a shallow subtidal zone near the mouth. Several pocket marshes and shallow ponds occur in Elkhorn Slough. These areas are isolated from the main channel by the Southern Pacific Railroad tracks. The tide range along the main channel in Elkhorn Slough is $1.7 \mathrm{~m}$.

Agricultural land-use occurs on about $26 \%$ of the watershed and is dominated by row crops such as strawberries, flowers, artichokes and raspberries (Fig. 1). Most of the land is zoned rural residential, with a majority of the homes using septic systems. Urban and commercial land uses represent about $16 \%$ of the land cover and are concentrated in the towns of Moss Landing and Castroville. About $10 \%$ of the watershed is protected and managed in its natural state by a variety of state and federal agencies, or private non-profit organizations.

In this study, we examined seasonal changes in overlying water nutrient and chlorophyll a ( $\mathrm{chl}$ a), and pore 
water $\mathrm{NH}_{4}{ }^{+}$, dissolved inorganic phosphate (DIP) and $\mathrm{S}^{2-}$ in 5 sites throughout Elkhorn Slough. Sites were chosen on the basis of their proximity to various land uses in the region. These sites received runoff either from agriculture and other non-point sources, or from grasslands and woodlands. These sites also spanned a gradient from poorly to well flushed water exchange. Benthic fluxes of O, N, P and Si were compared at 3 of the 5 sites.

\section{MATERIALS AND METHODS}

Site description. Five sites were chosen to represent a range of environments in the slough from the main stem to isolated pocket marsh ponds. Water and sediment samples were collected between February 1998 and November 1999 (Fig. 1). Sampling was usually conducted at low tide. During the first year of this study, 3 sites were sampled monthly between February and November. Two of the sites (Hudson's Landing and Lower Azevedo Pond) are adjacent to agricultural fields and directly receive non-point source runoff, while the third site (Hidden Pond), is surrounded by grasslands. Two additional sites were added in 1999 in order to include some well-flushed sites representative of the central slough (Hummingbird Island) and the mouth of the estuary (Vierra mudflat). Hudson's Landing, Vierra mudflat and Hummingbird Island were sampled in February, March, July, and November 1999. Hidden and Lower Azevedo Ponds were also sampled in July 1999. All sites were characterized by fine-grained, muddy sediments except for Vierra mudflat, which was muddy sand.

Runoff and tidal flushing were quite different at each site. Hudson's Landing is adjacent to a pickleweed marsh at the head of Elkhorn Slough. It is exposed at low tides $(+1.0 \mathrm{~m}$ mean low low water [MLLW]). This site receives runoff from agricultural fields (strawberries, flowers and truck crops), a cattle pasture, golf course and the unincorporated town of Los Lomas. Lower Azevedo Pond (referred to in the text as Azevedo Pond) is a tidal pond $\left(4300 \mathrm{~m}^{2}\right)$, bounded on one side by railroad tracks and on the other side by strawberry fields extending to the upper edge of the pickleweed marsh. This site is poorly flushed with the only water exchange between the pond and the main channel of Elkhorn Slough occurring via seepage through a blocked culvert. Hidden Pond is located on the Elkhorn Slough National Estuarine Research Reserve (ESNERR). It is a small tidal pond $\left(2600 \mathrm{~m}^{2}\right)$ bounded by railroad tracks and pickleweed marsh and surrounded by grasslands. A culvert allows for moderate flushing with the main channel of Elkhorn Slough. Both ponds generally had 5 to $30 \mathrm{~cm}$ of overlying water except during the lowest tides. The Hummingbird Island site is also located on the ESNERR near Hidden Pond and receives runoff from nearby grasslands. This site is a mudflat adjacent to the main channel and is exposed during low tides (+0.45 m MLLW). Vierra mudflat is located near the mouth of the slough and is extremely well flushed. Sediments are exposed at low tides (+0.2 m MLLW).

Sampling. Water samples were collected for chl a and nutrient analysis in plastic bottles, and returned to the lab on ice, where the samples were filtered. The chlorophyll filters and nutrient samples were frozen until analysis. Sediment cores (several types, see below for descriptions) were collected at each site for pore water nutrient analysis, benthic fluxes, percent water and percent organic matter. In July 1999, cores were collected for measurement of depth of $\mathrm{O}_{2}$ penetration using $\mathrm{O}_{2}$ microelectrodes. Temperature and salinity were measured at all sites at the time of sampling.

Benthic flux cores: Triplicate cores $(6 \mathrm{~cm}$ diameter $)$ were collected at each site along with approximately $10 \mathrm{l}$ of water. Only 2 sites were sampled on each trip, due to the labor and time commitment required for flux measurements. Water height in the cores was 25 to $35 \mathrm{~cm}$, while sediment thickness was 15 to $20 \mathrm{~cm}$. The cores were brought back to the lab in the dark in coolers filled with ambient water from the sites to maintain temperature. Cores were gently aerated by bubbling to maintain ambient conditions, near saturation, and held in a controlled temperature room for $20 \mathrm{~h}$ before conducting experiments. The bubbling was stopped, overlying water was replaced with the collected water and cores were sealed with tops equipped with a magnetic stirring system and sampling ports. Cores were incubated in the dark at ambient temperatures. The first water sample $(30 \mathrm{ml})$ was taken after a $1 \mathrm{~h}$ incubation period and 3 additional samples were removed at subsequent $1 \mathrm{~h}$ intervals. Water removed from the cores was replaced with water from the sampling site. Water samples were filtered through GF/F filters for nutrient $-\mathrm{NH}_{4}{ }^{+}, \mathrm{NO}_{3}{ }^{-}+\mathrm{NO}_{2}{ }^{-}, \mathrm{NO}_{2}{ }^{-}, \mathrm{DSi}$ (dissolved silicate) and DIP - analysis, or placed unfiltered in glass bottles $\left(7 \mathrm{ml}\right.$ ) with Winkler reagents for $\mathrm{O}_{2}$ analysis.

Pore water constituents: Triplicate sediment cores ( $4.6 \mathrm{~cm}$ diameter) were collected at each site for analysis of pore water constituents. Within $4 \mathrm{~h}$ of collection, sediments were sliced into 0 to $0.5,0.5$ to 1,1 to 2 and 2 to $4 \mathrm{~cm}$ sections in a $\mathrm{N}_{2}$ filled glove bag, placed in $50 \mathrm{ml}$ centrifuge tubes and spun to remove pore waters. An aliquot (approximately $0.5 \mathrm{ml}$ ) was used for sulfide analysis, the remainder was filtered through GF/F filters and frozen for analysis of $\mathrm{NH}_{4}{ }^{+}$and DIP. Pore water $\mathrm{S}^{2-}$ concentrations were measured monthly between February and July 1998, in October 1998, 
November 1998, July 1999 and November 1999. The water content and organic matter content of surficial (0 to $0.5 \mathrm{~cm}$ ) sediments was determined by drying 10 to $15 \mathrm{~g}$ wet weight of sediment at $60^{\circ} \mathrm{C}$ for $48 \mathrm{~h}$. Sediment samples were reweighed and combusted at $450^{\circ} \mathrm{C}$ for $12 \mathrm{~h}$ to determine loss on ignition (L01).

$\mathrm{O}_{2}$ profiles: Clark style oxygen microelectrodes (100 $\mu \mathrm{m}$ tip diameter, Diamond General Development Corp., Ann Arbor, MI, USA) were used to measure $\mathrm{O}_{2}$ concentrations in pore waters at Hudson's Landing, Azevedo Pond, Hidden Pond and Hummingbird Island sites in July 1999. A single core (9.5 cm diameter) was collected at each site and returned to the lab. Overlying water was gently aerated by bubbling before and during measurements. A micromanipulator was used to position the microelectrodes at $100 \mu \mathrm{m}$ depth increments to measure $\mathrm{O}_{2}$ concentrations. Triplicate profiles were measured in each core.

Analytical techniques: Water samples from the benthic flux experiments (above) were fixed with Winkler reagents for determination of dissolved $\mathrm{O}_{2}$ and stored in $7 \mathrm{ml}$ glass bottles. $\mathrm{O}_{2}$ concentrations were measured within $4 \mathrm{~h}$ of collection using the starch endpoint titra- tion method (APHA 1985). All nutrient samples were analyzed within 3 mo of collection on a Lachet autoanalyzer using standard seawater methods provided by Lachet (Lachet Instruments). Total dissolved sulfides $\left(\mathrm{H}_{2} \mathrm{~S}, \mathrm{HS}^{-}, \mathrm{S}^{2-}\right)$, referred to in the text as $\mathrm{S}^{2-}$, were analyzed using the methylene blue method (Parsons et al. 1984). Frozen chlorophyll samples were extracted overnight in $90 \%$ acetone. The acetone extracts were centrifuged and read on a Turner Model 10 fluorometer (Turner Designs) (Parsons et al. 1984).

Pore water flux calculations: Pore water nutrient concentrations were used to calculate fluxes across the sediment-water interface according to Fick's first law of diffusion:

$$
J=\varnothing D s \delta C / \delta x
$$

where $J$ is the flux, $\varnothing$ is porosity, Ds is the effective diffusion coefficient, and $\delta C / \delta \mathrm{x}$ is the concentration gradient. The linear portions of profiles were used to calculate the concentration gradient. The effective diffusion coefficient equals $D ø$, where $D$ is the molecular diffusion coefficient: $2.3 \times 10^{-5} \mathrm{~cm} \mathrm{~s}^{-1}$ for $\mathrm{O}_{2}$ (Lerman 1979), $1.96 \times 10^{-5} \mathrm{~cm} \mathrm{~s}^{-1}$ for $\mathrm{NH}_{4}^{+}$(Berner 1980), $1.63 \times$
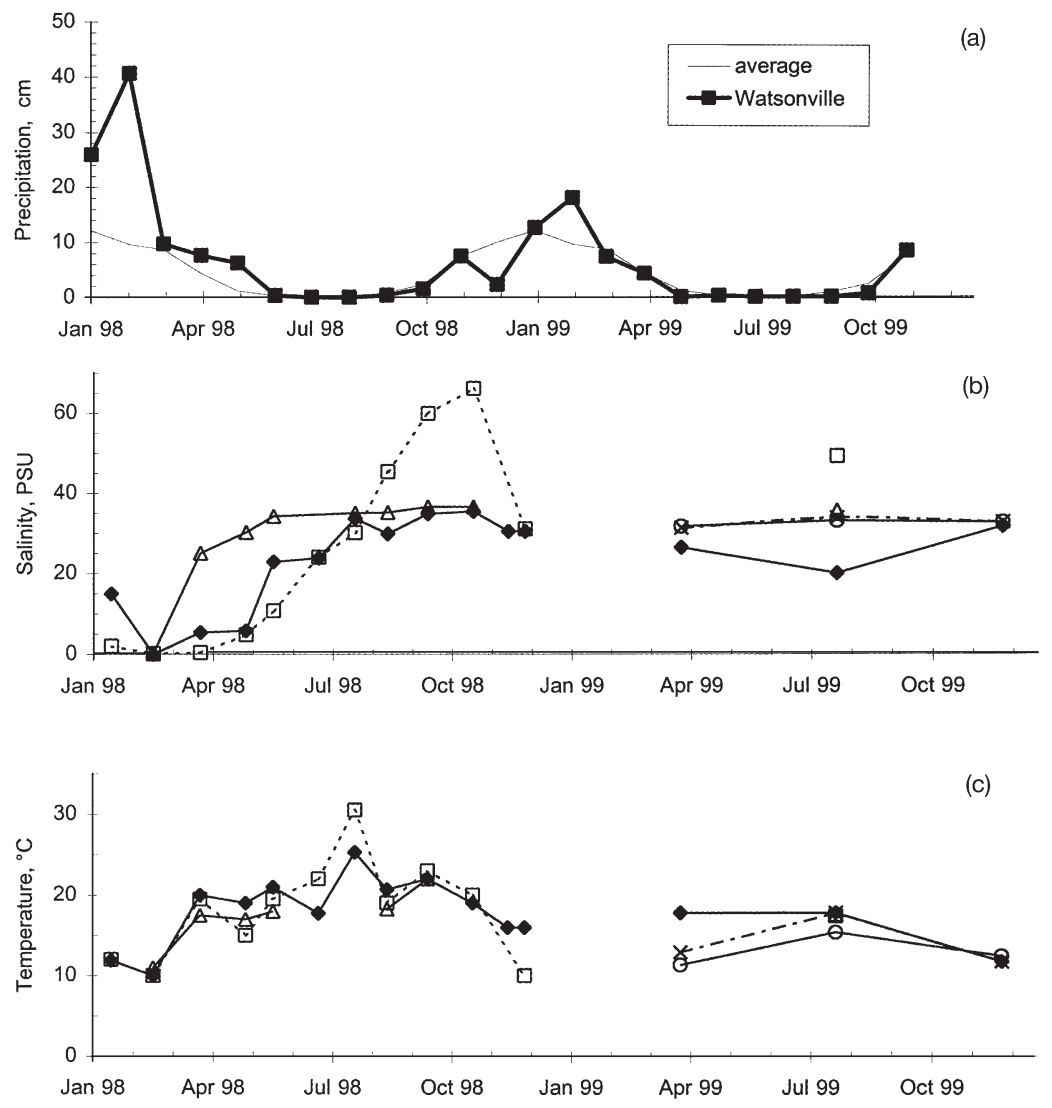

Fig. 2. (a) Precipitation during study period and $50 \mathrm{yr}$ average precipitation $(\mathrm{cm})$ at Watsonville, CA (approximately $10 \mathrm{~km}$ from

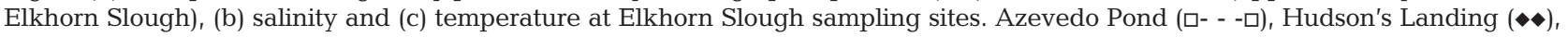
Hidden Pond $(\Delta-\Delta)$, Hummingbird Island $(\times----\times)$, Vierra mudflat $(0-0)$ 
$10^{-5} \mathrm{~cm} \mathrm{~s}^{-1}$ for DIP (Berner 1980) and $2.53 \times 10^{-5} \mathrm{~cm} \mathrm{~s}^{-1}$ for $\mathrm{S}^{2-}$ (Roden \& Tuttle1993). In the text, these fluxes are referred to as diffusive fluxes to distinguish them from the fluxes measured by incubating sediment cores.

Statistical analysis: We performed ANOVA to examine site and seasonal differences in pore water constituents and benthic fluxes. Correlation analysis was also performed examine relationships among constituents and benthic fluxes. Systat (Version 9; SPSS Science) was used for all analyses.

\section{RESULTS}

\section{Water column constituents}

Central California has a Mediterranean climate with most rainfall normally occurring between October and May, and maximum rainfall occurring between December and March. In January and February 1998, rainfall was 2 to 3 times higher than the 50 yr average and continued to be above average into May (Fig. 2a). In 1999, rainfall was generally similar to the 50 yr average, except for February (above average) and November (below average). Salinity declined during the rainy season, reaching a minimum in February 1998 when all stations were fresh (Fig. 2b). Salinities gradually increased throughout the summer and fall, reaching peaks of 35.4, 36.5 and 66 PSU in October at Hudson's Landing, Hidden Pond and Azevedo Pond, respectively. Azevedo Pond also had the most extreme temperature variations between $7^{\circ} \mathrm{C}$ in December and $30^{\circ} \mathrm{C}$ in July (Fig. 2c). Temperatures at the other sites were similar and ranged between 10 and $25^{\circ} \mathrm{C}$ (Fig. 2c).

Water column $\mathrm{NO}_{3}^{-}+\mathrm{NO}_{2}^{-}$concentrations were often high following heavy rain events and were inversely correlated with salinity ( $p=0.01, r=-0.45)$, although there was considerable variation between sites (Fig. 3). $\mathrm{NO}_{3}{ }^{-}+\mathrm{NO}_{2}{ }^{-}$concentrations were always high at the head of the slough (Hudson's Landing), usually in excess of $50 \mu \mathrm{M}$, while concentrations at the mouth (Vierra mudflat) were below $15 \mu \mathrm{M}$. On average, $\mathrm{NO}_{2}^{-}$concentrations represented about $20 \%$
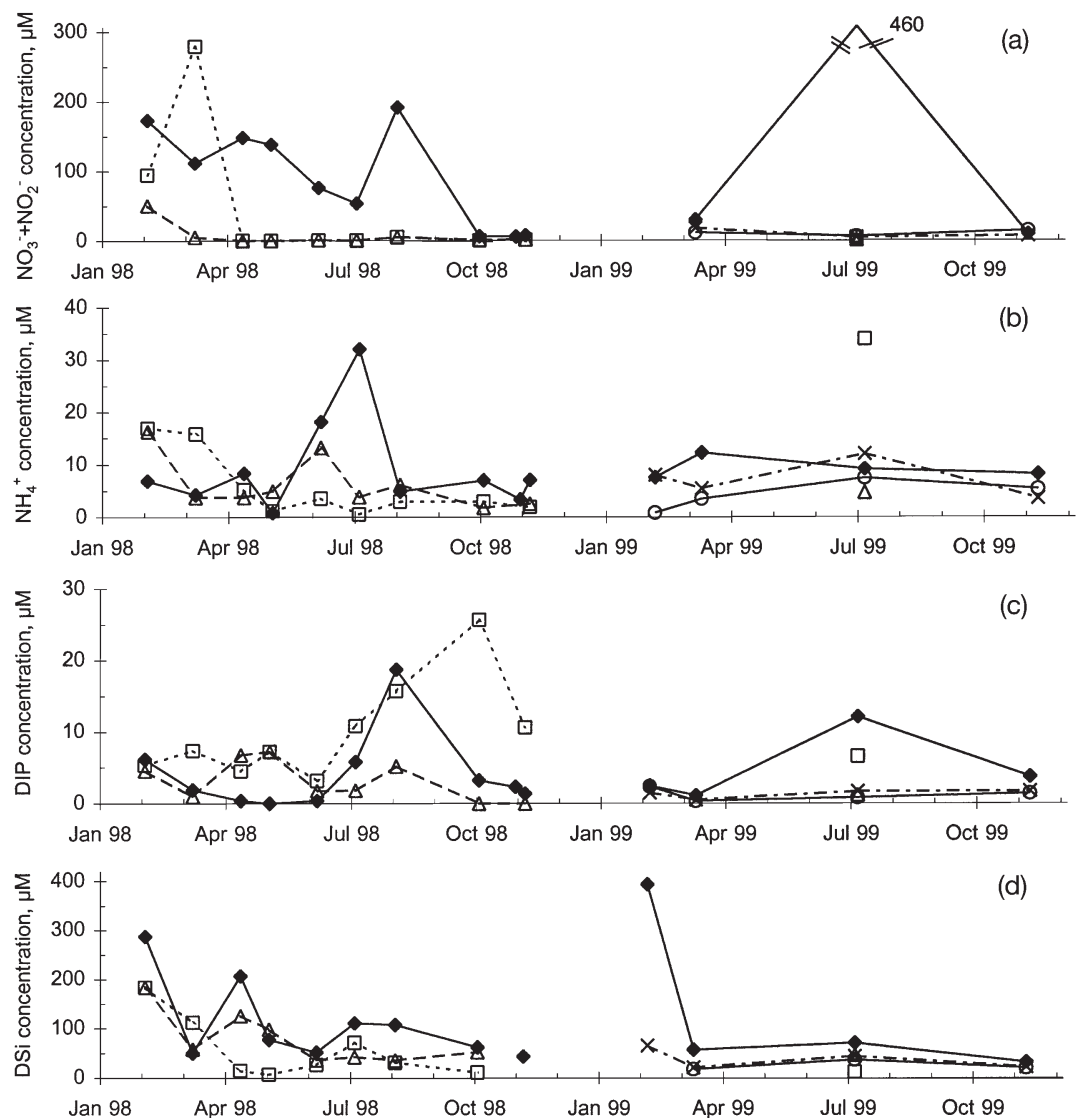

Fig. 3. Nutrient concentrations $(\mu \mathrm{M})$ at sampling sites in Elkhorn Slough: (a) $\mathrm{NO}_{3}{ }^{-}+\mathrm{NO}_{2}{ }^{-}$, (b) $\mathrm{NH}_{4}{ }^{+}$, (c) DIP, (d) DSi. Azevedo Pond $(\square---\square)$, Hudson's Landing $(\bullet \bullet)$, Hidden Pond $(\Delta-\Delta)$, Hummingbird Island $(\times----\times)$, Vierra mudflat $(\circ-\circ)$ 


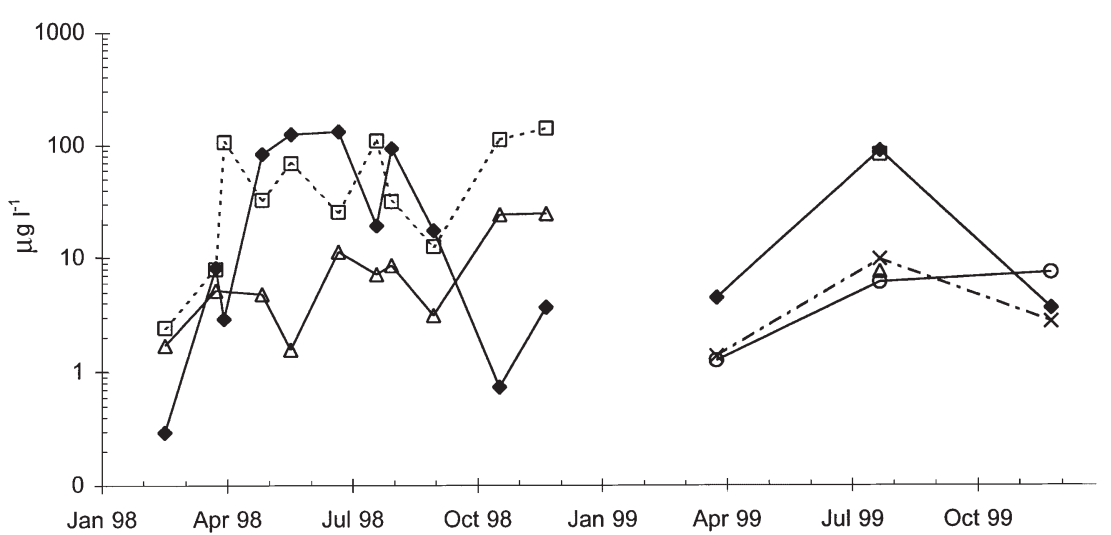

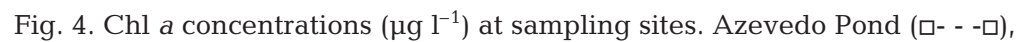
Hudson's Landing $(\bullet)$, Hidden Pond $(\Delta-\Delta)$, Hummingbird Island $(\times----\times)$ Vierra mudflat (o-०) of the $\mathrm{NO}_{3}^{-}+\mathrm{NO}_{2}^{-}$concentration, although the percentage ranged between 2 and $100 \%$ depending on location and site. Water column $\mathrm{NH}_{4}{ }^{+}$ concentrations were usually above $3 \mu \mathrm{M}$ at all sites and were particularly high at Azevedo Pond in the early spring and Hudson's Landing and Hidden Pond in the summer, when concentrations exceeded $13 \mu \mathrm{M}$ (Fig. 3). Water column DIP concentrations were highest in late summer, particularly at the sites receiving agricultural runoff (Hudson's Landing and Azevedo Pond) where concentrations exceeded $15 \mu \mathrm{M}$ (Fig. 3). DSi concentrations were usually highest following runoff events and inversely correlated with salinity $(\mathrm{p}=0.001$,
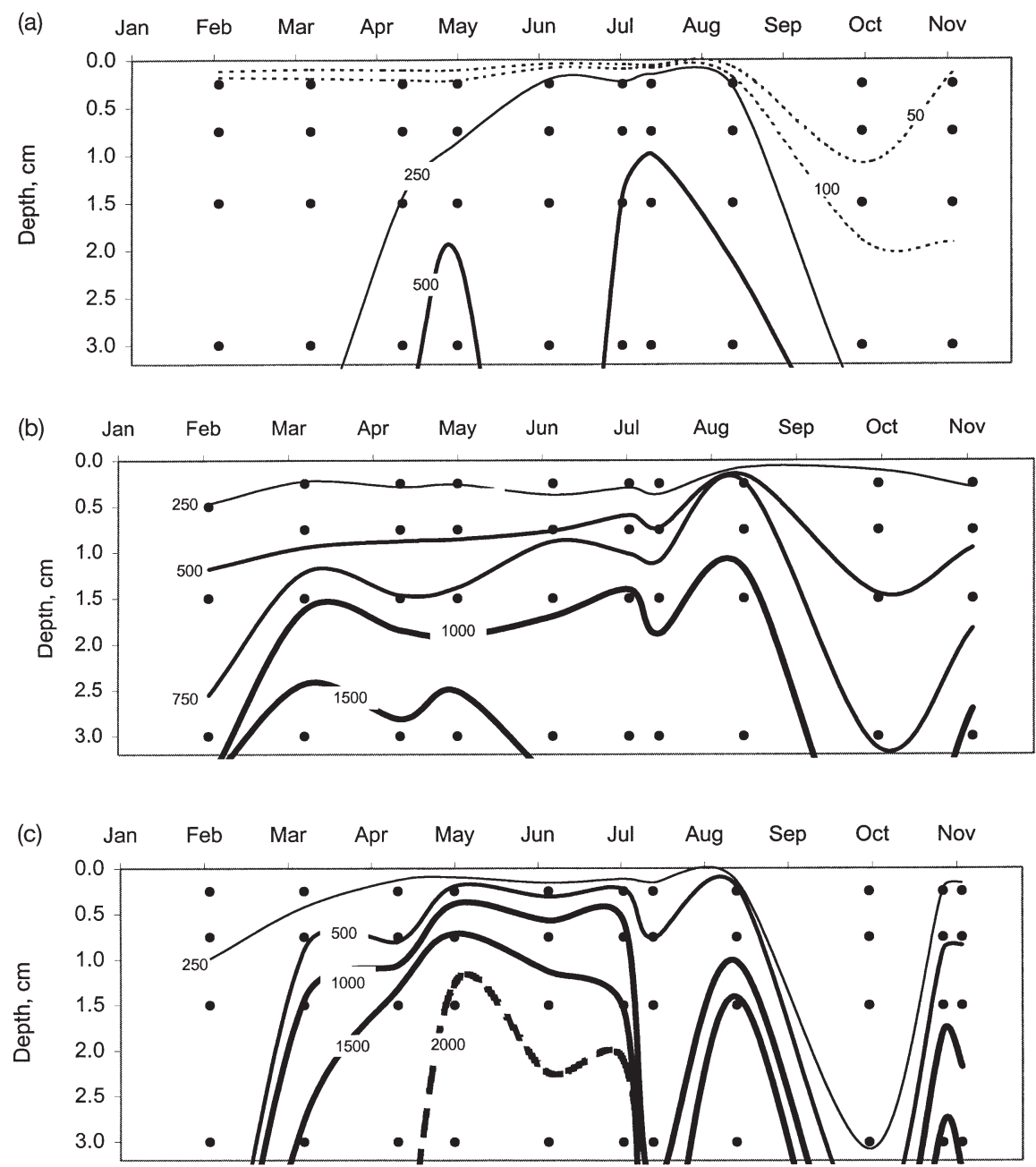

Fig. 5. Contour plot of pore water $\mathrm{NH}_{4}{ }^{+}$concentrations $(\mu \mathrm{M})$ with depth and sampling period at (a) Hidden Pond, (b) Azevedo Pond and (c) Hudson's Landing in 1998 
$\mathrm{r}=-0.59$ ), particularly at the head of the slough (Hudson's Landing). $\mathrm{NO}_{3}^{-}+\mathrm{NO}_{2}^{-}, \mathrm{NO}_{2}^{-}$, and DSi were all significantly positively correlated with one another at all sites and times ( $\mathrm{p}<0.04)$.

Chl a concentrations varied by station and season in Elkhorn Slough (Fig. 4). At the head of the slough (Hudson's Landing), chl a concentrations usually exceeded $80 \mu \mathrm{g} \mathrm{l}^{-1}$ throughout the summer. The other site receiving agricultural runoff, Azevedo Pond, exhibited no distinct seasonal pattern and concentrations ranged between 2.4 and $140 \mu \mathrm{g} \mathrm{l}^{-1}$. In Hidden Pond, values ranged between 1.5 and $24.6 \mu \mathrm{g} \mathrm{l}^{-1}$ with peak concentrations occurring in October and November. Chl a concentrations in the central slough (Hummingbird Island) and at the mouth of the slough (Vierra mudflat) were always below $10 \mu \mathrm{g} \mathrm{l}^{-1}$.

\section{Pore water constituents}

Pore water concentrations of $\mathrm{NH}_{4}{ }^{+}, \mathrm{DIP}$ and $\mathrm{S}^{2-}$ exhibited consistent seasonal and spatial patterns at the different sampling sites. Concentrations always increased with depth in sediment and were generally the highest in the summer, particularly at the agricultural site at the head of the slough (Hudson's Landing). Pore water $\mathrm{NH}_{4}{ }^{+}$concentrations were lowest at the non-agricultural site (Hidden Pond) with concentrations rarely exceeding $500 \mu \mathrm{M}$ even at 2 to $4 \mathrm{~cm}$ depth interval (Fig. 5). In contrast, summer pore water $\mathrm{NH}_{4}{ }^{+}$ concentrations were above 1000 and $2000 \mu \mathrm{M}$ at the 2 to $4 \mathrm{~cm}$ depth interval at the 2 agricultural sites, Azevedo Pond and Hudson's Landing, respectively (Fig. 5). Seasonal patterns and site differences were similar for pore water DIP and $\mathrm{S}^{2-}$ concentrations

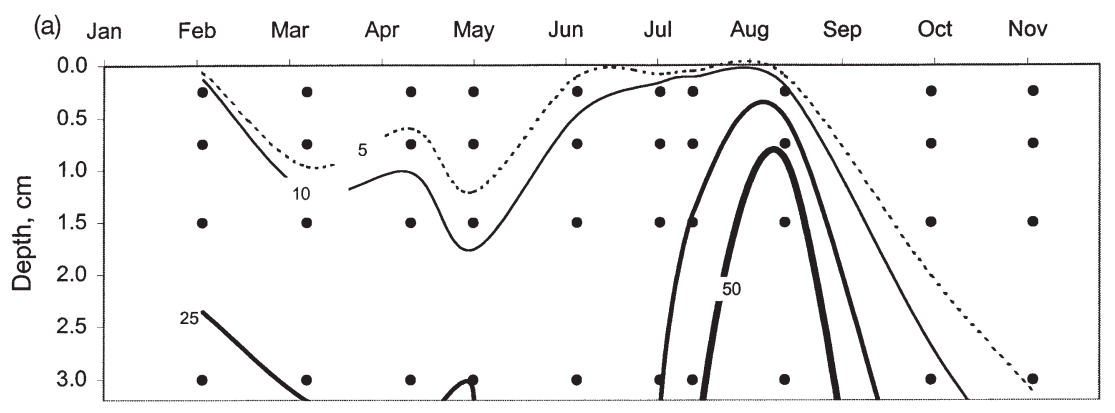

(b) Jan Feb Mar Apr May Jun Jul Aug Sep Oct Nov
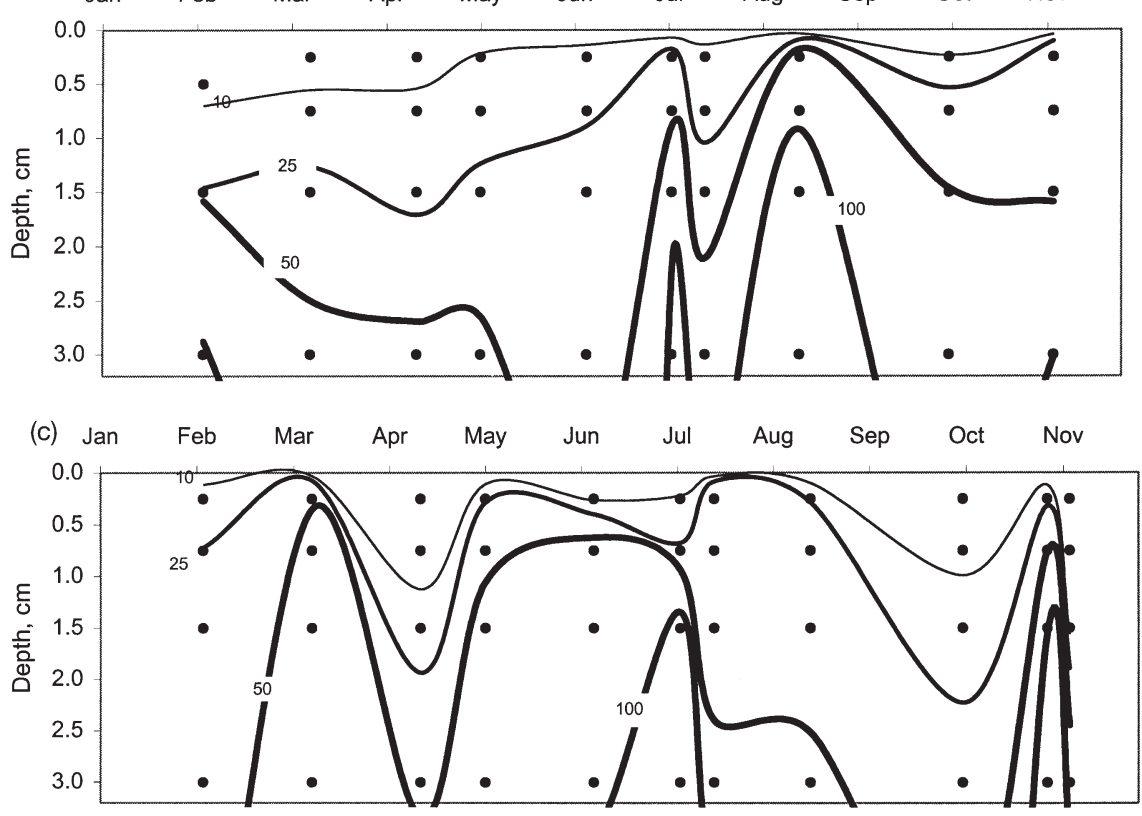

Fig. 6. Contour plot of pore water DIP concentrations $(\mu \mathrm{M})$ with depth and sampling period at (a) Hidden Pond, (b) Azevedo Pond and (c) Hudson's Landing in 1998 

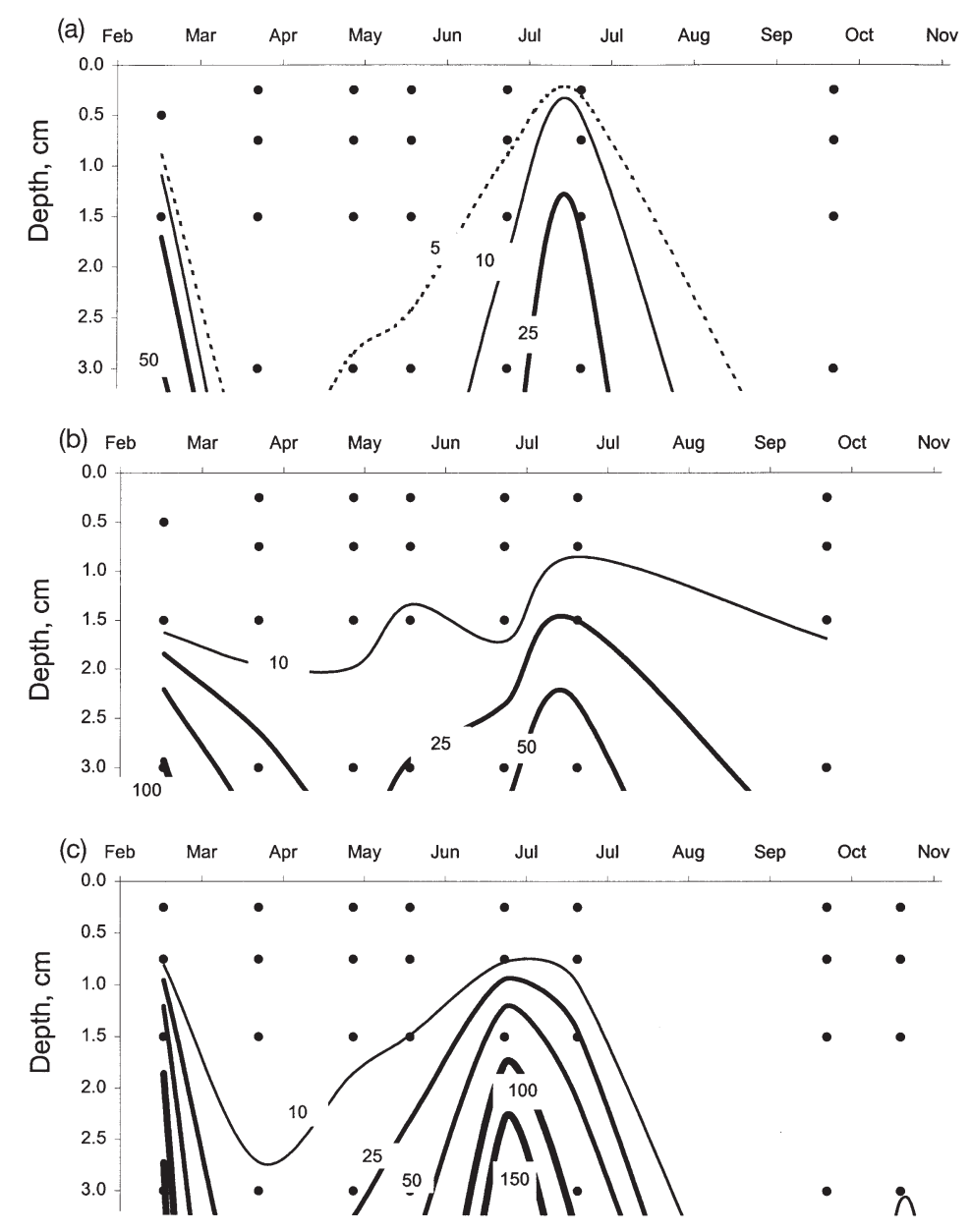

Fig. 7. Contour plot of pore water $\mathrm{S}^{2-}$ concentrations $(\mu \mathrm{M})$ with depth and sampling period at (a) Hidden Pond, (b) Azevedo Pond and (c) Hudson's Landing in 1998

(Figs. 6 \& 7), which were lowest at Hidden Pond and highest at Hudson's Landing, particularly in the summer.

Concentrations of pore water $\mathrm{NH}_{4}{ }^{+}$, DIP and $\mathrm{S}^{2-}$ in 1999 were similar to those of 1998 , with the highest

Table 1. Sediment water content and organic matter content at Elkhorn Slough sampling sites, mean and standard error (SE)

\begin{tabular}{|lcccc|}
\hline Station & $\begin{array}{c}\text { Water content } \\
(\%) \\
\text { Mean }\end{array}$ & SE & $\begin{array}{c}\text { Organic content } \\
(\%) \\
\text { Mean }\end{array}$ & SE \\
\hline Hudson's Landing & 76 & 2 & 17 & 2 \\
Lower Azevedo Pond & 70 & 1 & 13 & 1 \\
Hidden Pond & 68 & 2 & 14 & 1 \\
Hummingbird Island & 36 & 5 & $7^{\mathrm{a}}$ & 1 \\
Vierra mudflat & 20 & 1 & 0.48 & 0.02 \\
aFrom Caffrey (1996) & & & & \\
\hline
\end{tabular}

concentrations occurring in July at Hudson's Landing (Fig. $8 ; \mathrm{NH}_{4}{ }^{+}$, other data not shown). Pore water $\mathrm{NH}_{4}{ }^{+}$ concentrations at the mouth (Vierra mudflat) and central slough (Hummingbird Island) were usually very low, often less than $150 \mu \mathrm{M}$ even at the 2 to $4 \mathrm{~cm}$ depth, except during February (Fig. 8). Similar seasonal patterns were observed at the 3 sites for pore water DIP and $\mathrm{S}^{2-}$ (data not shown). Pore water $\mathrm{NH}_{4}{ }^{+}, \mathrm{DIP}$ and $\mathrm{S}^{2-}$ were all significantly positively correlated with one another $(p<0.001)$. ANOVA for each of the pore water constituents indicated that both station and depth were significant variables $(p<0.001)$, while date was only significant for $\mathrm{NH}_{4}{ }^{+}$concentrations $(\mathrm{p}=0.003)$.

In July 1999, dissolved $\mathrm{O}_{2}$ concentrations measured using $\mathrm{O}_{2}$ microelectrodes decreased rapidly with increasing depth in sediments. The depth of dissolved $\mathrm{O}_{2}$ penetration was greatest at the Hummingbird Island site $(6.0 \mathrm{~mm})$, intermediate at Hidden Pond $(2.1 \mathrm{~mm})$ and least at Hudson's Landing $(0.9 \mathrm{~mm})$ and Azevedo Pond (1.1 mm) (Fig. 9). 
The water content of sediments showed little seasonal variation. Annual averages are shown in Table 1 for each site. Similarly, organic matter content was fairly constant over the year except in Azevedo Pond. Organic matter content at this site declined from 27 to $9.4 \%$ between November and March, and then gradually increased back to November levels by the fall (data not shown). Average organic matter content was highest in Azevedo Pond (17\% LOI) and lowest at Vierra mudflat $(0.5 \%$ LOI) (Table 1).

\section{Benthic fluxes}

SOC was very similar at the 2 agricultural sites, Hudson's Landing and Azevedo Pond during March and April 1998 (Table 2), although in May 1998 SOC was significantly higher in Azevedo Pond than at Hudson's Landing. In 1999, SOC at a non-agricultural site at the mouth (Vierra mudflat) was about $1 / 5$ of the rates at an agricultural site (Hudson's Landing) during the same period. ANOVA revealed that there were significant differences among stations and dates $(\mathrm{p}=0.002)$.
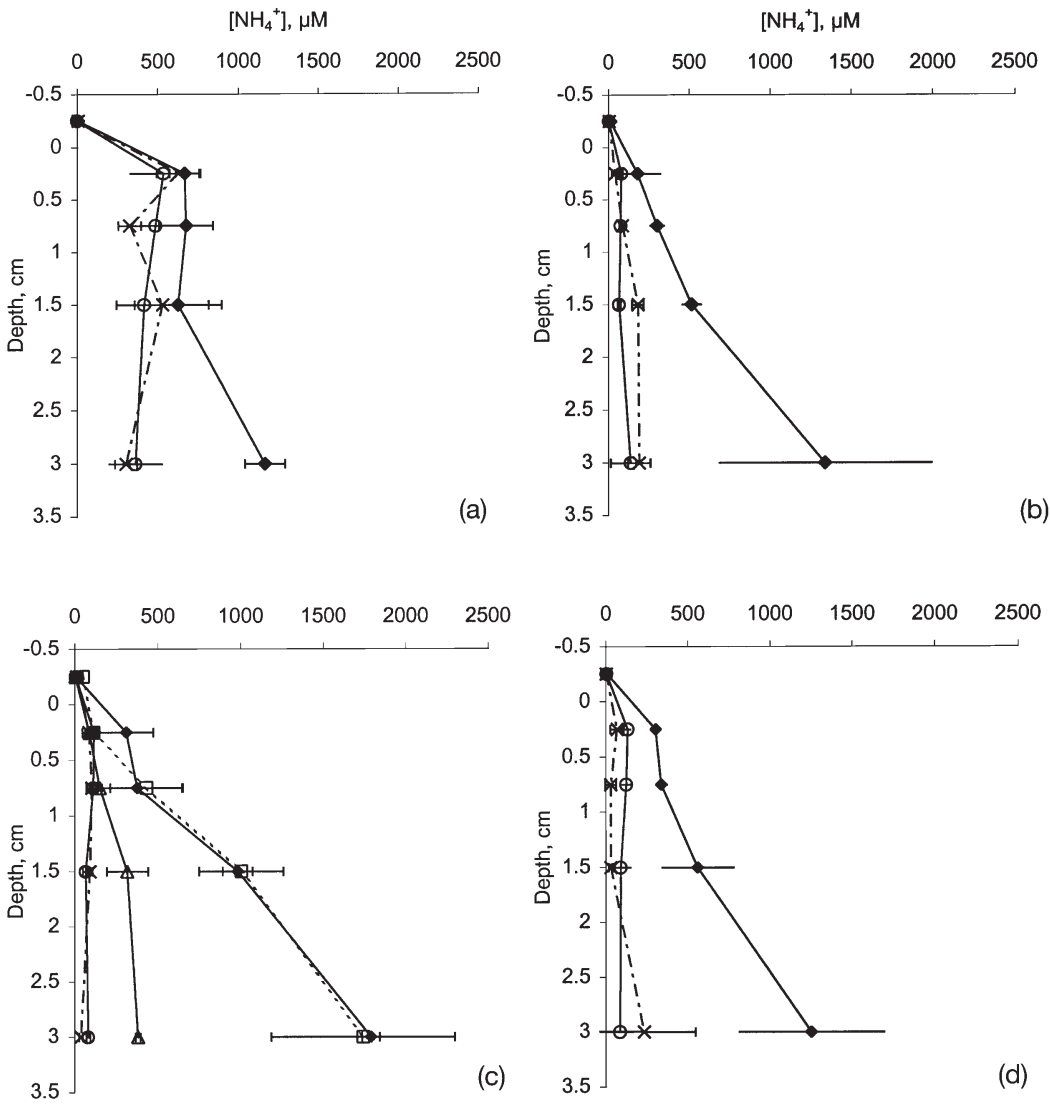

Fig. 8. Pore water $\mathrm{NH}_{4}^{+}$concentrations $(\mu \mathrm{M})$ at Vierra mudflat $(\mathrm{O}-\mathrm{O})$, Hummingbird Island $(\times---\times)$, Hudson's Landing $(\bullet \bullet)$, Hidden Pond $(\Delta-\Delta)$, and Azevedo Pond ( $\square-$ - $^{-}$) in (a) February, (b) March, (c) July and (d) November 1999. Mean \pm SE $(n=3)$

Table 2. Benthic fluxes from intact core incubations. Sediment oxygen consumption (SOC), $\mathrm{NH}_{4}^{+}$flux, $\mathrm{NO}_{3+2}{ }^{-}$flux, $\mathrm{NO}_{2}^{-}$flux, $\mathrm{NO}_{3}{ }^{-}$, dissolved inorganic phosphate (DIP) flux and dissolved silica (DSi) fluxes in Elkhorn Slough, mean and standard error (SE). Rates in $\mathrm{mmol} \mathrm{m}^{-2} \mathrm{~d}^{-1}$

\begin{tabular}{|c|c|c|c|c|c|c|c|c|c|c|c|c|c|c|}
\hline \multirow{2}{*}{$\begin{array}{c}\text { Station } \\
\text { Date }\end{array}$} & \multicolumn{2}{|c|}{$\mathrm{SOC}$} & \multicolumn{2}{|c|}{$\mathrm{NH}_{4}^{+}$} & \multicolumn{2}{|c|}{$\mathrm{NO}_{3+2}{ }^{-}$} & \multicolumn{2}{|c|}{$\mathrm{NO}_{2}^{-}$} & \multicolumn{2}{|c|}{$\mathrm{NO}_{3}{ }^{-}$} & \multicolumn{2}{|c|}{ DIP } & \multicolumn{2}{|c|}{ DSi } \\
\hline & Mean & $\mathrm{SE}$ & Mean & $\mathrm{SE}$ & Mean & $\mathrm{SE}$ & Mean & $\mathrm{SE}$ & Mean & $\mathrm{SE}$ & Mean & $\mathrm{SE}$ & Mean & $\mathrm{SE}$ \\
\hline \multicolumn{15}{|c|}{ Lower Azevedo Pond } \\
\hline Mar 98 & 33.7 & 1.9 & 8.6 & 2.9 & -3.29 & 2.11 & 1.30 & 0.45 & -4.43 & 2.67 & 0.28 & 1.34 & -13.38 & 2.39 \\
\hline Apr 98 & 48.6 & 29.3 & 8.1 & 2.6 & -0.31 & 0.12 & 0.44 & 0.58 & -0.75 & 0.61 & 1.08 & 0.52 & -0.25 & 1.91 \\
\hline May 98 & 54.8 & 7.4 & -0.4 & 0.5 & 0.07 & 0.07 & 0.27 & 0.38 & -0.21 & 0.17 & 0.97 & 1.04 & 16.30 & 1.96 \\
\hline \multicolumn{15}{|c|}{ Hudson's Landing } \\
\hline Mar 98 & 37.1 & 2.0 & 3.1 & 0.7 & -3.93 & 2.66 & 1.51 & 1.67 & -5.44 & 4.32 & -0.45 & 0.10 & 2.80 & 7.54 \\
\hline Apr 98 & 37.3 & 21.8 & 13.8 & 5.6 & -0.71 & 0.32 & 6.62 & 4.09 & -7.33 & 4.39 & 0.32 & 0.19 & 34.87 & 4.92 \\
\hline May 98 & 24.2 & 2.0 & 5.9 & 4.6 & 1.92 & 0.58 & 2.27 & 0.18 & -0.35 & 0.76 & -0.10 & 0.40 & 0 & 0 \\
\hline Nov 98 & 57.8 & 9.6 & 3.8 & 0.6 & -1.11 & 0.68 & -0.13 & 0.05 & -0.98 & 0.63 & -0.28 & 0.19 & 0 & 0 \\
\hline Mar 99 & 66.4 & 15.9 & 9.6 & 3.3 & -7.20 & 1.64 & -0.24 & 0.26 & -6.96 & 1.89 & 1.22 & 0.10 & 12.9 & 8.5 \\
\hline Jul 99 & 49.5 & 29.6 & 0.1 & 4.1 & 4.30 & 16.01 & 3.35 & 2.54 & 0.95 & 17.68 & -5.55 & 2.75 & -0.8 & 1.1 \\
\hline Nov 99 & 107.5 & 35.9 & 3.2 & 3.2 & -0.21 & 0.33 & -0.07 & 0.09 & -0.14 & 0.27 & -0.69 & 0.56 & 2.8 & 2.1 \\
\hline \multicolumn{15}{|c|}{ Vierra Mudflat } \\
\hline Mar 99 & 12.9 & 7.3 & -1.0 & 1.2 & 1.86 & 1.28 & 0.04 & 0.05 & 1.82 & 1.25 & 0.06 & 0.08 & 1.7 & 1.1 \\
\hline Jul 99 & 7.3 & & 1.4 & 1.3 & -0.55 & 0.98 & 0.02 & 0.02 & -0.57 & 0.99 & -0.11 & 0.10 & 0 & 0 \\
\hline Nov 99 & 19.0 & 2.0 & 0.4 & 0.3 & -0.39 & 0.25 & -0.04 & 0.04 & -0.35 & 0.28 & 0.05 & 0.13 & -1.37 & 1.11 \\
\hline
\end{tabular}




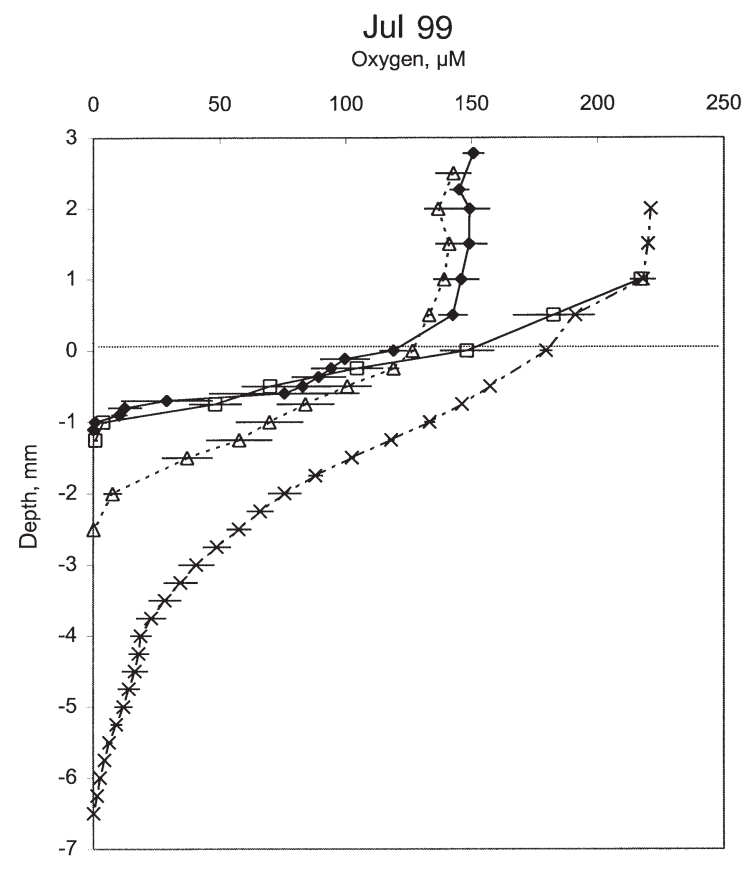

Fig. 9. Dissolved oxygen concentrations $(\mu \mathrm{M})$ in sediments from Hummingbird Island $(\times----\times)$, Hudson's Landing $(\bullet \bullet)$, Hidden Pond $(\Delta-\Delta)$ and Azevedo Pond (- - - ) in July 1999. Mean $\pm \operatorname{SE}(n=3)$

The temporal and spatial patterns for SOC and $\mathrm{NH}_{4}{ }^{+}$ fluxes were similar at the 3 sites. $\mathrm{NH}_{4}{ }^{+}$release from sediments was usually comparable at the agricultural sites (Hudson's Landing and Azevedo Pond), except in May at Azevedo Pond when fluxes were near zero (Table 2). In contrast, the non-agricultural site at the mouth (Vierra mudflat) had very low fluxes that varied in direction between $\mathrm{NH}_{4}{ }^{+}$release and uptake by sediments (Table 2). Rates were significantly different between different stations and dates $(\mathrm{p}=0.003)$.

In general, $\mathrm{NO}_{3}^{-}+\mathrm{NO}_{2}^{-}$uptake by sediments occurred at the agricultural sites (Hudson's Landing and Azevedo Pond) and the non-agricultural site at the mouth (Vierra mudflat), although rates were much lower at the non-agricultural site (Table 2). On several occasions, $\mathrm{NO}_{3}{ }^{-}+\mathrm{NO}_{2}^{-}$release occurred, at the agricultural sites in May 1998 and July 1999 (Hudson's Landing site) and at the mouth (Vierra mudflat) in March 1999 (Table 2). There were no significant differences in rates between different stations and dates. $\mathrm{NO}_{2}{ }^{-}$release from sediments was observed at the agricultural sites on most sampling dates, with particularly high release (over $1.5 \mathrm{mmol} \mathrm{m}^{-2} \mathrm{~d}^{-1}$ ) at Hudson's Landing between March and May 1998, and in July 1999 (Table 2). Rates at the estuary mouth (Vierra mudflat) were near 0 for all sampling dates. Rates were significantly different between stations and dates $(p=0.01)$.
$\mathrm{NO}_{3}{ }^{-}$uptake (calculated by subtracting $\mathrm{NO}_{2}{ }^{-}$flux from $\mathrm{NO}_{3}{ }^{-}+\mathrm{NO}_{2}{ }^{-}$flux) was observed at all sites except on 2 occasions, Vierra mudflat in March 1999 and Hudson's Landing in July 1999.

DIP fluxes were near zero at Vierra mudflat while DIP release consistently occurred at Azevedo Pond on all sampling dates (Table 2). Rates were variable at Hudson's Landing showing either small uptake or release in 1998, but higher values in 1999 (Table 2). ANOVA indicated that rates were significantly different between stations and dates $(p<0.001)$. DSi fluxes were also quite variable and significantly different between stations and dates $(\mathrm{p}<0.001)$. There was a significant release of DSi from Hudson's Landing sediments on about half of the sampling dates; on the remaining dates, rates were near 0. In Azevedo Pond in 1998, DSi was taken up by sediments in March, there was no net flux in April and DSi was released by sediments in May. Rates at Vierra mudflat were low and varied between uptake and release by sediments.

\section{Diffusive fluxes}

Diffusive $\mathrm{NH}_{4}{ }^{+}, \mathrm{DIP}$ and $\mathrm{S}^{2-}$ fluxes were estimated based on pore water concentrations (Table 3). Diffusive $\mathrm{NH}_{4}{ }^{+}$fluxes were generally highest during the summer when pore water concentrations were high. Seasonal patterns were not as distinct in DIP and $\mathrm{S}^{2-}$ fluxes where rates were at a minimum during the spring. Diffusive $\mathrm{NH}_{4}{ }^{+}, \mathrm{DIP}$ and $\mathrm{S}^{2-}$ fluxes were highest at Hudson's Landing and Azevedo Pond, intermediate at Hidden Pond and Hummingbird Island, and lowest at Vierra mudflat. Diffusive $\mathrm{O}_{2}$ flux, measured in July 1999, showed a similar pattern with rates of $23 \mathrm{mmol}$ $\mathrm{m}^{-2} \mathrm{~d}^{-1}$ at Hudson's Landing and Azevedo Pond, $9.4 \mathrm{mmol} \mathrm{m}^{-2} \mathrm{~d}^{-1}$ at Hidden Pond, and $8.1 \mathrm{mmol} \mathrm{m}^{-2} \mathrm{~d}^{-1}$ at Hummingbird Island.

\section{DISCUSSION}

The distinct seasonal pattern of central California's rainfall leads to extreme variation in runoff and nutrient inputs to estuaries such as Elkhorn Slough. Rain and runoff were important sources of nutrient input to the slough. Nutrient input and concentration patterns were also clearly related to land use, as seen in the high variability and high concentrations of nutrients in sites nearest to agricultural sources, whereas sites situated in the mainstream of the slough and near the mouth of the estuary were less variable and never experienced the highest concentrations detected upstream. Nutrient inputs from agricultural runoff were particularly evident at Lower Azevedo Pond which was 
Table 3. Diffusive fluxes calculated from pore water $\mathrm{NH}_{4}{ }^{+}$, DIP and $\mathrm{S}^{2-}$ concentrations using Fick's first law. Rates in $\mathrm{mmol} \mathrm{m} \mathrm{m}^{-2} \mathrm{~d}^{-1}$. nd $=$ no data

\begin{tabular}{|c|c|c|c|}
\hline $\begin{array}{l}\text { Station } \\
\text { Date }\end{array}$ & $\mathrm{NH}_{4}^{+}$ & DIP & $\mathrm{S}^{2-}$ \\
\hline \multicolumn{4}{|c|}{ Lower Azevedo Pond } \\
\hline Feb 98 & 3.5 & 0.57 & 1.61 \\
\hline Mar 98 & 7.4 & 0.28 & 0.40 \\
\hline Apr 98 & 6.6 & 0.23 & 0.15 \\
\hline May 98 & 7.3 & 0.22 & 0.18 \\
\hline Jun 98 & 5.8 & 0.18 & 0.32 \\
\hline Jul 98 & 5.7 & 0.47 & 0.45 \\
\hline Aug 98 & 3.8 & 0.27 & nd \\
\hline Sep 98 & 4.0 & 0.50 & nd \\
\hline Oct 98 & 2.9 & 0.28 & 0.12 \\
\hline Nov 98 & 4.3 & 0.31 & nd \\
\hline Jul 99 & 7.8 & 0.51 & nd \\
\hline \multicolumn{4}{|c|}{ Hudson's Landing } \\
\hline Feb 98 & 3.0 & 0.25 & 1.07 \\
\hline Mar 98 & 6.8 & 2.15 & 0.14 \\
\hline Apr 98 & 13.0 & 0.18 & 0.14 \\
\hline May 98 & 12.4 & 0.33 & 0.28 \\
\hline Jun 98 & 9.4 & 0.34 & 1.04 \\
\hline Jul 98 & 10.7 & 0.66 & 0.53 \\
\hline Aug 98 & 0.3 & -0.13 & nd \\
\hline Sep 98 & 5.6 & 0.16 & nd \\
\hline Oct 98 & 0.9 & 0.14 & 0.003 \\
\hline Nov 98 & 6.4 & 0.66 & nd \\
\hline Nov 98 & 5.1 & 0.29 & nd \\
\hline Feb 99 & 3.7 & 0.16 & nd \\
\hline Mar 99 & 5.3 & 0.06 & nd \\
\hline Jul 99 & 7.3 & 0.25 & 0.06 \\
\hline Nov 99 & 4.8 & 0.07 & 0.45 \\
\hline \multicolumn{4}{|c|}{ Hidden Pond } \\
\hline Feb 98 & 0.5 & 0.36 & 0.33 \\
\hline Mar 98 & 0.7 & 0.10 & nd \\
\hline Apr 98 & 1.5 & 0.07 & 0.03 \\
\hline May 98 & 2.6 & 0.11 & 0.04 \\
\hline Jun 98 & 1.2 & -0.01 & 0.09 \\
\hline Jul 98 & 2.2 & 0.07 & 0.19 \\
\hline Aug 98 & 0.9 & 0.02 & nd \\
\hline Sep 98 & 1.2 & -0.12 & nd \\
\hline Oct 98 & 0.7 & -0.005 & 0.01 \\
\hline Nov 98 & 0.5 & 0.01 & nd \\
\hline Jul 99 & 1.7 & 0.09 & nd \\
\hline \multicolumn{4}{|c|}{ Hummingbird Island } \\
\hline Feb 99 & 0.5 & -0.04 & nd \\
\hline Mar 99 & 1.4 & 0.002 & nd \\
\hline Jul 99 & 1.2 & -0.005 & 0.0006 \\
\hline Nov 99 & 0.8 & 0.01 & nd \\
\hline \multicolumn{4}{|c|}{ Vierra mudflat } \\
\hline Feb 99 & 1.31 & -0.003 & nd \\
\hline Mar 99 & 0.09 & 0.0001 & nd \\
\hline Jul 99 & 0.02 & -0.005 & 0.000 \\
\hline Nov 99 & 0.03 & -0.008 & nd \\
\hline
\end{tabular}

surrounded by strawberry fields and isolated from tidal mixing with the slough. High nutrient inputs led to high production of organic matter as shown by the chl a concentrations in the water column (Fig. 4) and extensive mats of macroalgae on intertidal mudflats (Allen 1992). Deposition of phytoplankton to sediments as well as burial of macroalgal biomass resulted in high organic matter concentrations at several of the sampling sites.

The pattern of sediment organic matter content indicated large differences among sampling sites, consistent with nutrient inputs and chl a concentrations. Organic matter content usually exceeded 10\% (Table 1). These organic matter values were much higher than values observed in other estuarine sediments such as Long Island Sound (Mackin \& Swider 1989), Buzzards Bay (Banta et al. 1995), Chesapeake Bay (Roden \& Tuttle 1993, Reay et al. 1995) and San Francisco Bay (Hammond et al. 1985, Caffrey 1995), where values range between 2 and $8 \%$. Decomposition of this organic matter led to high pore water $\mathrm{NH}_{4}{ }^{+}$, DIP and $\mathrm{S}^{2-}$ concentrations, particularly in the summer. Except for Hidden Pond, sites with high organic matter content had high pore water nutrient concentrations. The difference between Hidden Pond and other sites with high organic matter content may have been because the major source of the organic matter in Hidden Pond sediments was pickleweed from the marsh surrounding the pond and that plant material was more refractory than phytoplankton or macroalgae. Pore water concentrations were lowest at the mouth at the sandy Vierra mudflat site where the organic matter content was only $0.5 \%$.

The depth of oxygen penetration also reflected the varying intensity of decomposition and available organic matter at the different sites. The least penetration occurred at the agricultural sites (Hudson's Landing and Azevedo Pond) and the greatest at a non-agricultural site in the central Slough (Hummingbird Island) (Fig. 9). Despite having an organic matter content as high as the agricultural sites at Hidden Pond, the depth of $\mathrm{O}_{2}$ penetration was twice that of the agricultural sites. Perhaps organic matter at Hidden Pond was less labile than at the agricultural sites. Oxygen penetration at Vierra mudflat was not measured. Differences in organic content of the sediments were consistent with the observed variation in benthic fluxes among sites. Low organic matter concentrations at the non-agricultural site at the mouth (Vierra mudflat) resulted in lower rates of decomposition and thus lower SOC and $\mathrm{NH}_{4}^{+}$release from sediments compared to the agricultural sites (Hudson's Landing or Azevedo Pond). These results are consistent with previous research from Elkhorn Slough showing high SOC and $\mathrm{NH}_{4}{ }^{+}$fluxes at sites receiving agricultural runoff compared to sites receiving runoff from the National Estuarine Research Reserve (Caffrey 1996).

In addition to sediment organic matter, other factors influencing benthic fluxes include overlying water 

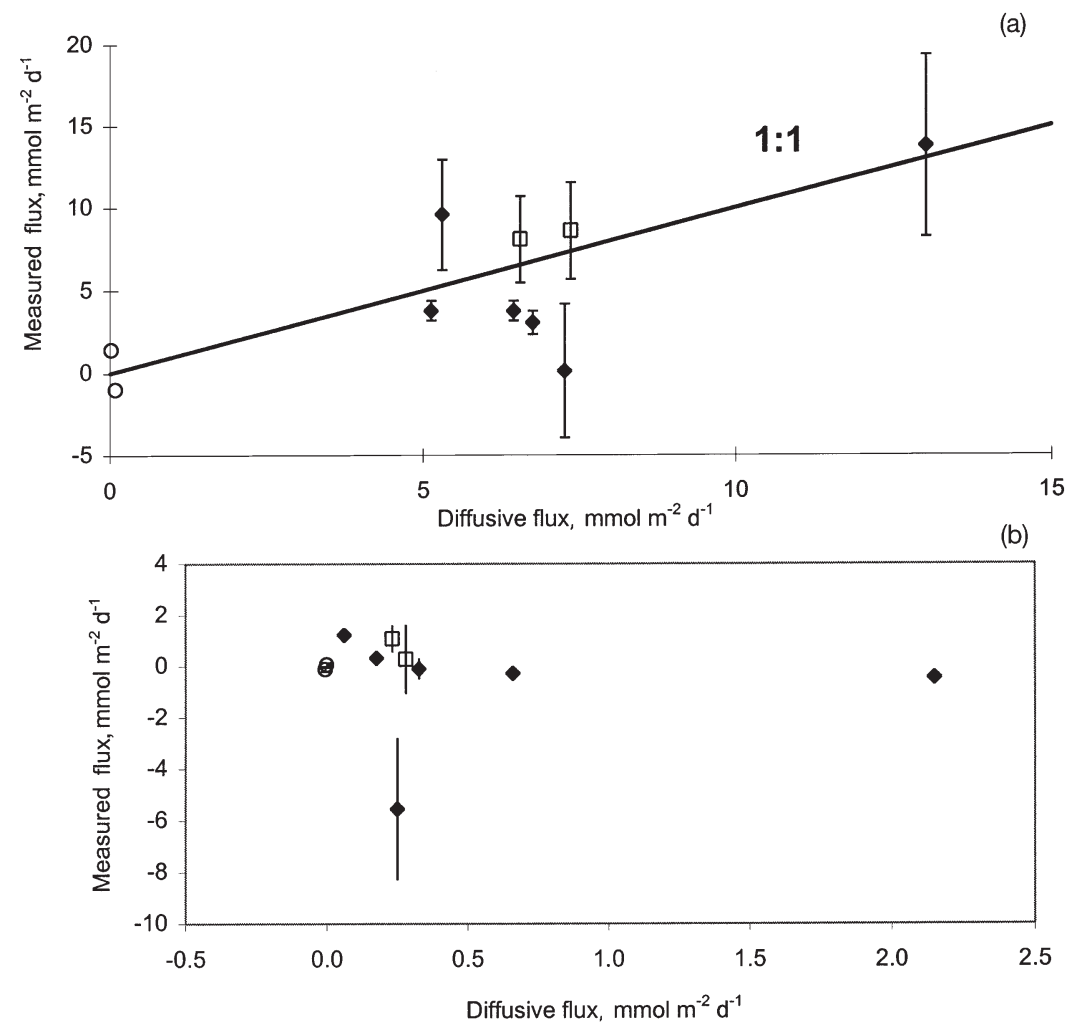

Fig. 10. Measured fluxes versus calculated diffusive fluxes of (a) $\mathrm{NH}_{4}{ }^{+}$and (b) DIP

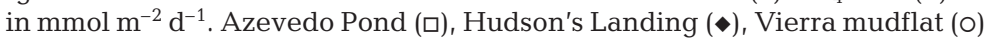

suggesting that diffusion of pore water $\mathrm{NH}_{4}{ }^{+}$was not the sole determinant of the benthic $\mathrm{NH}_{4}{ }^{+}$flux, and that some pore water $\mathrm{NH}_{4}{ }^{+}$was removed either by benthic micro- or macroalgae or by nitrification (Fig. 10a). There was no correlation between diffusive and measured DIP fluxes (Fig. 10b), probably because both measured and calculated fluxes were very close to 0. Pore water DIP way have been adsorbed to $\mathrm{FEOOH}$ at the aerobic sediment-water interface and thus was unable to diffuse across the sediment-water interface.

Benthic macrofauna can greatly enhance fluxes across the sedimentwater interface by bioturbation as well as excretion of $\mathrm{NH}_{4}{ }^{+}$(Hammond et al. 1985, Mackin \& Swider 1989, Peligri \& Blackburn 1994, Banta et al. 1995, Caffrey et al. 1996). Often the diffusion coefficient used in the diffusive flux calculation is increased to account for macrofauna bioturbation (Hammond et al. 1985, Mackin \& Swider 1989). In general, benthic macrofauna were not very abundant at these sites ( $\mathrm{J}$. Caffrey pers. obs.), so the diffusion coefficient was not adjusted in this study.

nutrient concentrations, sediment type, benthic macrofauna and benthic micro- and macroalgae. Nutrient concentrations in the overlying water were important, with lower concentrations in the overlying water than in pore water resulting in release of nutrients, while higher concentrations in the overlying water than pore water resulted in uptake by sediments. Water column concentrations and fluxes of DIP were significantly correlated $(p=0.03)$, as were concentrations and fluxes of $\mathrm{NO}_{2}^{-}(\mathrm{p}=0.02)$. DIP concentration and flux were negatively correlated $(r=-0.61)$, suggesting that water column DIP concentrations may control DIP flux across the sediment-water interface. In contrast, $\mathrm{NO}_{2}^{-}$concentration and flux were positively correlated $(\mathrm{r}=$ 0.64). Because $\mathrm{NO}_{2}{ }^{-}$concentrations in sediments were usually very low, we infer that production of $\mathrm{NO}_{2}^{-}$in sediments by nitrification or the reduction of $\mathrm{NO}_{3}{ }^{-}$to $\mathrm{NO}_{2}{ }^{-}$and subsequent flux out into the overlying water was responsible for the high water column concentrations. Water column concentrations and fluxes were not significantly correlated for the other nutrients.

Comparing diffusive and measured fluxes can also provide insights into the factors controlling exchange across the sediment-water interface. In general, measured $\mathrm{NH}_{4}{ }^{+}$fluxes were less than the diffusive flux,
However, on a majority of the occasions when macrofauna were present, measured $\mathrm{NH}_{4}{ }^{+}$fluxes were higher than diffusive fluxes. This was particularly apparent in March 1999 at Hudson's Landing when numerous amphipods were observed in the benthic flux cores.

Benthic micro- and macroalgae at the sediment-water interface can also remove nutrients from the water column. Although the highest uptake by micro- and macroalgae occurs in the light, some uptake can occur in the dark (Sundbäck et al. 1991, Thybo-Christesen et al. 1993). Benthic algal concentrations were not measured in this study. However, previous work found that benthic chl a levels in the top centimeter ranged from $21 \mathrm{mg} \mathrm{m}^{-2}$ at sites in the ESNERR to $574 \mathrm{mg} \mathrm{m}^{-2}$ at sites receiving agricultural runoff (Caffrey 1996). Nutrient uptake by this active community may explain the negative fluxes of DIP, $\mathrm{DSi}, \mathrm{NO}_{3}{ }^{-}+\mathrm{NO}_{2}{ }^{-}$and $\mathrm{NH}_{4}{ }^{+}$. Benthic diatoms, which are commonly observed in surficial sediments (K. Parker pers. comm.), may be responsible for the high DSi uptake occasionally observed. Nutrient uptake by benthic algae was probably underestimated, because all of the incubations were performed in the dark. Given the high nutrient inputs to Elkhorn Slough, further studies examining the role of benthic 


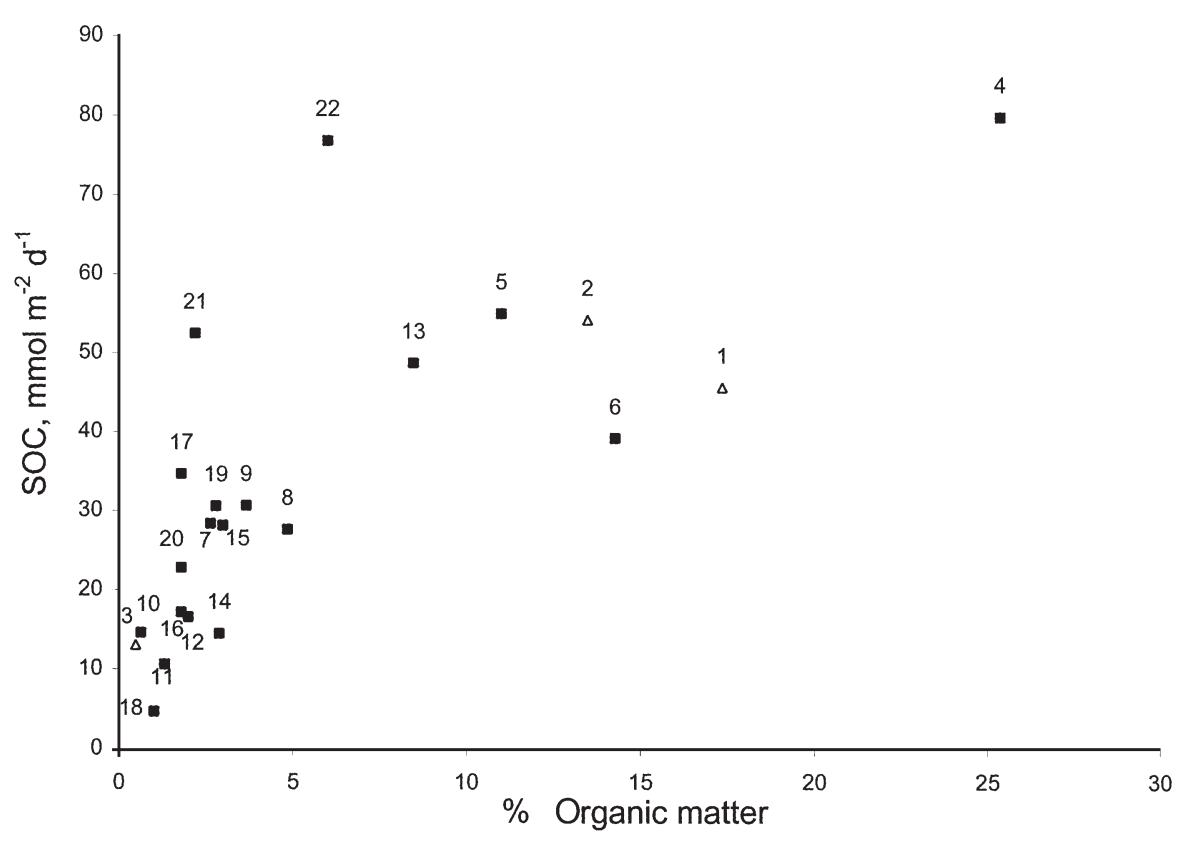

Fig. 11. Sediment oxygen consumption (SOC, $\mathrm{mmol} \mathrm{m}^{-2} \mathrm{~d}^{-1}$ ) versus \% organic matter in Elkhorn Slough and other estuaries. Elkhorn Slough (this study $\Delta$ ): 1 Azevedo Pond, 2 Hudson's Landing, 3 Vierra mudflat. Other studies: $\mathbf{}$. Elkhorn Slough: 4 Agricultural sites, 5 Grazing sites, 6 Reserve sites (Caffrey 1996), 7 San Francisco Bay (Hammond et al. 1985, Caffrey et al. 1996), 8 Chesapeake Bay (Kemp \& Boynton 1992, Reay et al. 1995), 9 Narragansett Bay (McCaffrey et al. 1980, Seitzinger et al. 1984), 10 Neuse River (Rizzo et al. 1992), 11 North Sea (Upton et al. 1993), 12 Bering Sea (Henriksen et al. 1993), 13 Parker River (Hopkinson et al. 1999), 14 Baltic Sea (Enoksson et al. 1990, Jørgensen 1996b), 15 Ochlockonee Bay (Twilley et al. 1999$), 16$ Mobile Bay (Twilley et al. 1999), 17 Fourleague Bay (Twilley et al. 1999), 18 Trinity-San Jacinto estuary (Twilley et al. 1999), 19 Guadeloupe estuary (Twilley et al. 1999), 20 Nueces estuary (Twilley et al. 1999), 21 Laguna Madre (Twilley et al. 1999), 22 Flax Pond (Mackin \& Swider 1989)

micro- and macroalgae in nutrient cycling are needed.

Benthic flux and pore water $\mathrm{NH}_{4}{ }^{+}$measurements from this study were similar to previous measurements in Elkhorn Slough (Caffrey 1996). SOC and $\mathrm{NH}_{4}{ }^{+}$flux from sites in Elkhorn Slough receiving agricultural and other non-point source runoff are among the highest recorded values from the literature (Nixon 1981, Hammond et al. 1985, Mackin \& Swider 1989, Enoksson et al. 1990, Dollar et al. 1991, Kamp-Nielsen 1992, Kemp \& Boynton 1992, Rizzo et al. 1992, Upton et al. 1993, Banta et al. 1995, Lohse et al. 1995, Reay et al. 1995, Caffrey et al. 1996, Hopkinson et al. 1999, Twilley et al. 1999, Mortazavi et al. 2000). In contrast, benthic fluxes from Vierra mudflat at the well-flushed mouth of Elkhorn Slough were similar to other estuarine and shallow coastal systems. Across many estuaries, sediment oxygen consumption is generally highest in systems with high sediment organic matter content (Fig. 11), although other factors such as water depth, bottom water column dissolved oxygen concentrations, sediment grain size, quality of organic matter and rate of organic matter deposition to sediments may also be significant.

This study suggests that high nutrient runoff has a local rather than estuary-wide effect on sediment bio- geochemical processes in Elkhorn Slough. At the head of Elkhorn Slough, where residence time during summer months reaches 50 d (Largier et al. 1997), high nutrient concentrations lead to increased chl a concentrations, high organic content in the sediments and ultimately high rates of benthic mineralization, particularly SOC and $\mathrm{NH}_{4}{ }^{+}$release. In contrast, nutrient inputs to the well-flushed, lower reaches of the slough are rapidly diluted by tidal exchange between Elkhorn Slough and Monterey Bay, resulting in low to moderate concentrations of $\mathrm{chl}$ a and sediment organic matter and low to moderate benthic remineralization. This is a sharp contrast to many stratified and partially stratified estuaries that have longer residence times and more estuarine-wide effects of high nutrient runoff (Kemp \& Boynton 1992, Nixon et al. 1996, Herbert 1999, Twilley et al. 1999). This study suggests that 2 factors appear to control the processing of organic matter in sediments: (1) proximity to agricultural or other non-point source runoff; and (2) tidal exchange or residence time within the system. These factors lead to large differences in nutrient and oxygen status of local environments, which can differ significantly from nearby sites and from the overall average conditions of the estuary. 
Acknowledgements. We thank Icarus Solem, Mary Hogan, Jennifer Mendoca, Rob Franks, Mike Murrell, Shirley Murphy, Rance Bratton, Cammy Chabret, Lisa Easley, Michelle Kirby, Marilyn McLoughlin, Martha Nitzberg, Jeanette Rudisill, and John Stacy for their assistance in the field and laboratory. This work was supported by NSF Biological Oceanography (OCE-9617690 to B.B.W.), an Earl and Ethyl Meyers Marine Biology Trust grant (to N.E.H.), and a graduate research fellowship (to N.E.H.) from the Sanctuaries and Reserve Division, OCRM, NOS (\#NA77OR02227).

\section{LITERATURE CITED}

Allen JK (1992) Benthic invertebrates living in macroalgal mats on intertidal mudflats of Elkhorn Slough, California. MSc thesis, San Jose State University

APHA (American Public Health Association) (1985) Standard methods for the examination of water and wastewater, Vol 16. American Public Health Association, Washington, DC

Balls PW (1994) Nutrient inputs to estuaries from nine Scottish east coast rivers: influence of estuarine processes on inputs to the North Sea. Estuar Coast Shelf Sci 39:329-352

Banta GT, Giblin AE, Hobbie JE, Tucker J (1995) Benthic respiration and nitrogen release in Buzzards Bay, Massachusetts. J Mar Res 53:107-135

Berner RA (1980) Early diagenesis. Princeton University Press, Princeton, NJ

Billen G, Somville M, De Becker E, Servais P (1985) A nitrogen budget of the Scheldt hydrographical basin. Neth J Sea Res 19:223-230

Bricker SB, Clement CG, Pirhalla DE, Orlando SP, Farrow DRG (1999) National Estuarine Eutrophication Assessment: effects of nutrient enrichment in the nation's estuaries. NOAA, National Ocean Service, Special Projects Office and the National Centers for Coastal Ocean Science. Silver Sring, MD

Caffrey JM (1995) Spatial and seasonal patterns in sediment ammonium concentrations and regeneration rates in San Francisco Bay, CA. Estuaries 18:219-233

Caffrey JM (1996) Effect of land-use practices on nutrient dynamics in subtidal estuarine sediments in Elkhorn Slough, CA. Final report to National Oceanic and Atmospheric Administration, Sanctuaries and Reserves Division. Grant \# NA47OR0198

Caffrey JM, Sloth NP, Kaspar H, Blackburn TH (1993) Effect of organic loading on nitrification and denitrification in a marine sediment microcosm. FEMS Microbiol Ecol 12: 159-167

Caffrey JM, Hammond DE, Kuwabara JS, Miller LG, Twilley RR (1996) Benthic processes in South San Francisco Bay: the role of organic inputs and bioturbation. In: Hollibaugh JT (ed) San Francisco Bay: the ecosystem. AAAS Pacific Division, San Francisco, CA, p 425-444

Cloern JE (2001) Our evolving conceptual model of the coastal eutrophication problem. Mar Ecol Prog Ser 210: 223-253

Conley DJ, Malone TC (1992) Annual cycle of dissolved silicate in Chesapeake Bay: implications for the production and fate of phytoplankton biomass. Mar Ecol Prog Ser 81: 121-128

Dollar SJ, Smith SV, Vink SM, Obrebski S, Hollibaugh JT (1991) Annual cycle of benthic nutrient fluxes in Tomales Bay, California, and contribution of the benthos to total ecosystem metabolism. Mar Ecol Prog Ser 79:115-125

Enoksson V, Sorensson F, Graneli W (1990) Nitrogen transformations in the Kattegat. Ambio 19:159-166
Graf G (1992) Benthic-pelagic coupling: a benthic view. Oceanogr Mar Biol Annu Rev 30:149-190

Hager SW, Schemel LE (1992) Sources of nitrogen and phosphorus to Northern San Francisco Bay. Estuaries 15:41-52

Hammond DE, Fuller C, Harmon D, Harman B and 6 others (1985) Benthic fluxes in San Francisco Bay. Hydrobiologia 129:69-90

Henriksen K, Blackburn TH, Lomstein BAa, McRoy CP (1993) Rates of nitrification, distribution of nitrifying bacteria and inorganic $\mathrm{N}$ fluxes in northern Bering-Chukchi shelf sediments. Cont Shelf Res 13:629-651

Herbert RA (1999) Nitrogen cycling in coastal marine ecosystems. FEMS Microbiol Rev 23:563-590

Hopkinson CS, Giblin AE, Tucker J, Garritt RH (1999) Benthic metabolism and nutrient cycling along an estuarine salinity gradient. Estuaries 22:863-881

Howarth RW (1988) Nutrient limitation of net primary production in marine ecosystems. Annu Rev Ecol 19:89-110

Jordan TE, Correll DL, Weller DE (1997) Relating nutrient discharges from watersheds to land use and streamflow variability. Water Resour Res 33:2579-2590

Jørgensen BB (1996a) Material flux in the sediment. In: Jørgensen BB, Richardson K (eds) Eutrophication in coastal marine ecosystems. American Geophysical Union, Washington, DC, p 115-135

Jørgensen BB (1996b) Case study-Aarhus Bay. In: Jørgensen BB, Richardson K (eds) Eutrophication in coastal marine ecosystems. American Geophysical Union, Washington, DC, p 137-154

Kamp-Nielsen L (1992) Benthic-pelagic coupling of nutrient metabolism along an estuarine eutrophication gradient. Hydrobiologia 235/236:457-470

Kemp WM, Boynton WR (1992) Benthic-pelagic interactions: nutrient and oxygen dynamics. In: Smith DE, Leffler $M$, Mackiernan G (eds) Oxygen dynamics in the Chesapeake Bay: a synthesis of recent research. Maryland Sea Grant, College Park, MD, p 149-221

Kemp WM, Sampou P, Caffrey J, Mayer M, Henriksen K, Boynton WR (1990) Ammonium recycling versus denitrification in Chesapeake Bay sediments. Limnol Oceanogr 35:1545-1563

Kemp WM, Sampou PA, Garber J, Tuttle J, Boynton WR (1992) Seasonal depletion of oxygen from bottom waters of Chesapeake Bay: roles of benthic and planktonic respiration and physical exchange processes. Mar Ecol Prog Ser 85:137-152

Largier JL, Hollibaugh JT, Smith SV (1997) Seasonally hypersaline estuaries in Mediterranean-climate regions. Estuar Coast Shelf Sci 45:789-797

Lerman A (1979) Geochemical processes in water and sediment environments. John Wiley \& Sons, New York

Lohse L, Malschaert FP, Slomp CP, Helder W, van Raaphorst W (1995) Sediment-water fluxes of inorganic nitrogen compounds along the transport route of organic matter in the North Sea. Ophelia 41:173-197

Mackin JE, Swider KT (1989) Organic matter decomposition pathways and oxygen consumption in coastal marine sediments. J Mar Res 47:681-716

McCaffrey RJ, Myers AC, Davey E, Morrisson G and 5 others (1980) The relation between pore water chemistry and benthic fluxes of nutrients and manganese in Narragansett Bay, RI. Limnol Oceanogr 25:31-44

Mortazavi B, Iverson RL, Huang W, Lewis FG, Caffrey JM (2000) Nitrogen budget of Apalachicola Bay, a bar-built estuary in the northeastern Gulf of Mexico. Mar Ecol Prog Ser 195:1-14

Nixon SW (1981) Remineralization and nutrient cycling in 
coastal marine ecosystems. Nutrients and estuaries. Humana Press, p 111-138

Nixon SW (1995) Coastal marine eutrophication: a definition, social causes, and future concerns. Ophelia 41:199-219

Nixon SW, Ammerman JW, Atkinson LP, Berounsky VM and 12 others (1996) The fate of nitrogen and phosphorus at the land-sea margin of the North Atlantic Ocean. Biogeochemistry 35:141-180

NRC (National Research Council) (2000) Clean coastal waters: understanding and reducing the effects of nutrient pollution. National Academy Press, Washington DC

Paerl HW, Mallin MA, Donahue CA, Go M, Peierls BL (1995) Nitrogen loading sources and eutrophication of the Neuse River estuary, North Carolina: direct and indirect roles of atmospheric deposition, Report No. 291. Water Resources Research Institute of the University of North Carolina Chapel Hill, NC

Parson TR, Maita Y, Lalli CM (1984) A manual of chemical and biological methods for seawater analysis. Pergamon Press, Oxford

Pelegri SP, Blackburn TH (1994) Bioturbation effects of the amphipod Corophium volutator on microbial nitrogen transformations in marine sediments. Mar Biol 121: 253-258

Reay WG, Gallagher DL, Simmons GM Jr (1995) Sedimentwater column oxygen and nutrient fluxes in nearshore environments of the lower Delmarva Peninsula, USA. Mar Ecol Prog Ser 118:215-227

Rizzo WM, Lackey GJ, Christian RR (1992) Significance of euphotic, subtidal sediments to oxygen and nutrient cycling in a temperate estuary. Mar Ecol Prog Ser 86:51-61

Editorial responsibility: Otto Kinne (Editor), Oldendorf/Luhe, Germany
Roden EE, Tuttle JH (1993) Inorganic sulfur cycling in mid and lower Chesapeake Bay sediments. Mar Ecol Prog Ser 93:101-118

Ryther JH, Dunstan WM (1971) Nitrogen, phosphorus and eutrophication in the coastal marine environment. Science 171:1008-1013

Seitzinger SP, Nixon SW, Pilson MEQ (1984) Denitrification and nitrous oxide production in a coastal marine ecosystem. Limnol Oceanogr 29:73-83

Staver LW, Staver KW, Stevenson JC (1996) Nutrient inputs to the Choptank River Estuary: implications for watershed management. Estuaries 19:342-358

Sundbäck K, Enoksson V, Graneli W, Pettersson K (1991) Influence of sublittoral microphytobenthos on the oxygen and nutrient flux between sediment and water: a laboratory continuous-flow study. Mar Ecol Prog Ser 74:263-279

Thybo-Christensen M, Rasmussen MB, Blackburn TH (1993) Nutrient fluxes and growth of Cladophora sericea in a shallow Danish bay. Mar Ecol Prog Ser 100:273-281

Twilley RR, Cowan J, Miller-Way T, Montagna PA, Mortazavi B (1999) Benthic nutrient fluxes in selected estuaries in the Gulf of Mexico. Chapter 6. In: Bianchi TS, Pennock JR, Twilley RR (eds) Biogeochemistry of Gulf of Mexico estuaries. Wiley-Liss, New York, p 163-209

Upton AC, Nedwell DB, Parkes RJ, Harvey SM (1993) Seasonal benthic microbial activity in the southern North Sea: oxygen uptake and sulphate reduction. Mar Ecol Prog Ser 101:273-281

Westrich JT, Berner RA (1984) The role of sedimentary organic matter in bacterial sulfate reduction: the $\mathrm{G}$ model tested. Limnol Oceanogr 29:236-249

Submitted: February 15, 2001; Accepted: November 15, 2001 Proofs received from author(s): April 24, 2002 